\title{
ANALISIS MARKETABLE SURPLUS DAN FAKTOR-FAKTOR YANG MEMPENGARUHI MARKETED SUPPLY SERTA KETERSEDIAAN BERAS DI KOTA BENGKULU
}

\author{
Nusril \\ M. Mustopha Romdhon \\ Riza Listaria \\ Jurusan Sosial Ekonomi Pertanian Fakultas Pertanian Universitas Bengkulu
}

\begin{abstract}
This research aim to estimate the amount marketable surplus of rice in Bengkulu City at one season plant March - June 2007; to identify factors influencing marketed supply of rice and to estimate availability of rice in Bengkulu City. Data collected were primary and secondary data. This research location determined using cluster sampling method with respondent of 89 persons selected using simple random sampli. The data analysis were used involving descriptive and multiple regression analysis estimated using ordinary least square method. The result show that: 1) percent marketable surplus of rice in Bengkulu City is 57,58\%, the ret is 42,62\%; 2) Factors influencing marketed supply of rice in Bengkulu City are : Rice price, cultivation index, and status of paddy farm.
\end{abstract}

Keyword: marketable surplus, marketed supply, rice, rice stock

\section{PENDAHULUAN}

Usahatani padi merupakan salah satu kegiatan pertanian yang mendapat perhatian dari berbagai pihak. Kegiatan usahatani padi menghasilkan makanan pokok dan merupakan sumber penerimaan sebagian besar pendududk indonesia. Padi atau beras masih memegang peran utama dalam konsumsi pangan di Indonesia sehingga seringkali pangan diidentikkan dengan padi atau beras. Oleh karena itu peningkatan produksi padi terus dilakukan dalam rangka meningkatkan ketahanan pangan nasioa (Sofyan 2006). Ketahanan pangan secara sederhana dapat di definisikan sebagai suatu keadaan dimana semua rumah tangga baik fisik maupun ekonomi mempunyai kemampuan mencukupi kebutuhan pangan untuk seluruh anggota keluarganya (Arifin et al 1997). 
Jumlah produksi padi tidak semuanya dipasarkan oleh petani, akan tetapi juga digunakan untuk konsumsi, sewa tanah, pajak, zakat, dan bibit. Hanya sebagian saja yang dijual atau dipasarkan untuk memenuhi kebutuhan hidup lainnya (marketable surplus). Oleh karena itu penelitian ini mencoba untuk mengetahui jumlah marketable surplus beras, faktor-faktor yang mempengaruhi marketed supply beras dan seberapa besar pengaruhnya terhadap ketersediaan beras di Kota Bengkulu dan ketersediaan beras di Kota Bengkulu.

\section{METODE PENELITIAN}

Lokasi penelitian ditentukan secara cluster yaitu dengan cara memilih lokasi dari kelompok-kelompok atau unit-unit yang terkecil (Nazir 1983), dimana lokasi penelitian berada di Kelurahan Dusun Besar untuk Kecamatan Gading Cempaka dan Kelurahan Kandang Limun untuk Kecamatan Muara Bangkahulu Kota Bengkulu dengan alasan lokasi ini merupakan salah satu daerah sentra produksi padi di Kota Bengkulu, memiliki lahan yang lebih luas dibandingkan dengan daerah lain berdasarkan jenis pengairan irigasi dan tadah hujan serta memiliki jumlah petani yang banyak.

Data pada penelitian ini bersumber dari data primer yang diperoleh melalui wawancara dengan 89 petani responden berdasarkan daftar pertanyaan yang telah disiapkan. Pengambilan petani sampel dilakukan dengan metode Simple Random Sampling, dimana sampel diambil secara random dan berimbang sebesar $20 \%$ dari populasi yang ada yakni 32 sampel di Kelurahan Dusun Besar dan 57 sampel di Kelurahan Kandang Limun.

Analisis data marketable surplus dilakukan dengan analisis data kuantitatif berdasarkan pengeluaran yang dikeluarkan langsung oleh petani (riil), yaitu menganalisa data yang diperoleh dilapangan dengan menggunakan angka-angka, dengan rumus:

Dimana:

$$
M S=Y-\left(X_{1}+X_{2}+X_{3}+X_{4}+X_{5}+X_{6}\right)
$$

MS = Marketable Surplus $(\mathrm{kg})$

$\mathrm{Y}=$ Total Produksi (kg/MT) 
$\mathrm{X}_{1}=$ Sewa Lahan $(\mathrm{Kg} / \mathrm{MT})$

$X_{2}=$ Bibit $(\mathrm{kg} / \mathrm{UT})$

$X_{3}=$ Upah Treser $(\mathrm{kg})$

$X_{4}=$ Upah Giling $(\mathrm{kg})$

$X_{5}=$ Konsumsi $(\mathrm{kg})$

$\mathrm{X}_{6}=$ Zakat $(\mathrm{kg} / \mathrm{UT})$

Analisis faktor-faktor yang mempengaruhi Marketed Supply beras digunakan persamaan linear berganda dengan metode kuadrat terkecil (Ordinary Least Squar) yang dirumuskan sebagai berikut:

$$
\text { Ms }=a_{0}+b_{1} X_{1}+b_{2} X_{2}+b_{3} X_{3}+a_{1} D_{1}+e
$$

Dimana:

Ms $=$ Marketed Supply (\%)

$X_{1}=$ Harga Beras $(\mathrm{Rp} / \mathrm{Kg})$

$X_{2}=$ Jumlah Penerimaan diluar Usahatani Padi (Rp/MT)

$\mathrm{X}_{3}=$ Indeks Pertanaman

$D_{1}=$ Status Penerimaan Usahatani Padi

$D_{1}=1$, Kalau Penerimaan Usahatani Padi Penerimaan Utama

$\mathrm{D}_{1}=0$, Kalau Penerimaan Luar Usahatani Padi Penerimaan Sampingan

$\mathrm{b}=$ Koefisien Regresi

$a_{0}=$ Konstanta

$\mathrm{e}=$ Variabel Pengganggu

Analisis data yang digunakan untuk menganalisis ketersediaan beras di Kota Bengkulu, dilakukan dengan analisis data deskriptif yaitu dengan cara menjelaskan dan memaparkan, menggambarkan dan menguraikan masalah dan pemecahannya yang ditemukan di lapangan tanpa ada perlakuan terhadap objek yang di teliti

\section{HASIL DAN PEMBAHASAN}

\section{Karakteristik Petani}

Hasil penelitian di Kelurahan Kandang Limun dan Kelurahan Dusun Besar menunjukkan rata-rata umur petani 44,62 dengan interval umur antara 27 sampai 75 tahun. Persentase terbesar dari umur responden usahatani padi di daerah penelitian terdapat pada kelompok umur antara 44 sampai 61 tahun yaitu sebesar 49,44\%, dan persentase terendah terdapat pada kelompok umur 
lebih dari 62 tahun yaitu sebesar 4,49\%. Persentase tersebut menunjukkan bahwa petani di daerah penelitian berada dalam usia produktif.

Sebagian besar dari petani telah menamatkan pendidikan Sekolah Dasar yaitu 38,20\%. Dari data ini dapat disimpulkan bahwa pendidikan petani di daerah penelitian masih rendah. Rendahnya tingkat pendidikan formal yang dimiliki petani disebabkan karena kondisi ekonomi masa lalu yang tidak mendukung untuk mendapatkan pendidikan yang lebih lama. Selanjutnya, berdasarkan hasil penelitian diperoleh rata-rata jumlah tanggungan petani di daerah penelitian sebanyak 3,73 atau 4 orang dengan interval antara 1 sampai 8 orang. Persentase jumlah anggota keluarga petani terbesar antara 4 sampai 6 orang adalah sebesar $51,69 \%$ sehingga dapat disimpulkan bahwa jumlah rata-rata anggota keluarga didaerah penelitian tidak terlalu besar karena hampir setengahnya memiliki jumlah anggota keluarga 1 sampai 3 yaitu $43,82 \%$.

Hasil penelitian menunjukkan bahwa rata-rata pengalaman petani padi dalam berusahatani adalah 17,55 tahun dengan interval antara 2 sampai 40 tahun. Persentase pengalaman berusahatani padi terbesar ada pada interval antara 2 sampai 15 tahun adalah sebesar $49,44 \%$. Jadi dapat disimpulkan bahwa petani di daerah penelitian sudah cukup berpengalaman.

Hasil penelitian juga menunjukkan bahwa rata-rata luas lahan yang diusahakan petani di daerah penelitian adalah 0,77 hektar dengan interval antara 0,14 sampai 1,5 hektar. Persentase terbesar penggunaan luas lahan untuk tanaman padi adalah antara 0,6 sampai 1,05 hektar atau sebesar $53,93 \%$, sedangkan persentase kepemilikan lahan usahatani terkecil $>1,05$ yaitu $5,62 \%$. Lahan yang dimiliki petani selain lahan sawah adalah lahan rumah dan perkarangan dengan ratarata 0,26 hektar.

Selain dari usahatani padi, petani juga memiliki penghasilan tambahan yaitu dari kebun. Di Kelurahan Kandang Limun dan Kelurahan Dusun Besar kebanyakan kebun ditanami kopi dan 
sawit. Rata-rata kepemilikan kebun dari responden adalah 0,24 hektar. Dari lampiran 4 diketahui jumlah persentase luas lahan kebun tersbesar ada pada interval $0-0,4$ hektar yaitu $74,16 \%$.

\section{Produksi dan Aloksi Penggunaan}

Jumlah rata-rata produksi dan alokasi penggunaan padi pada usahatani padi di Kelurahan Kandang Limun dan Kelurahan Dusun Besar berdasarkan pengeluaran yang benar-benar dikeluarkan petani secara langsung dalam bentuk natura lebih jelas dapat dilihat pada Tabel 1.

Tabel 1. Produksi dan Alokasi Produksi Padi Pada Usahatani Padi di Lokasi Penelitian

\begin{tabular}{lrrr}
\hline \multirow{2}{*}{ Uraian } & \multicolumn{2}{c}{ Rata-rata } & \multirow{2}{*}{ Persentase (\%) } \\
\cline { 2 - 3 } & Padi (kg) & Beras (kg) & 100 \\
\hline Produksi & 2265,63 & 1359,38 & 13,66 \\
Konsumsi & 309,44 & 185,66 & 1,34 \\
Bibit & 30,42 & 18,25 & 9,39 \\
Upah Treser & 212,69 & 127,61 & 8,63 \\
Upah Giling & 195,61 & 117,37 & 6,36 \\
Sewa Lahan & 143,97 & 86,38 & 3,24 \\
Zakat & 73,38 & 44,03 & 57,38 \\
Marketable Surplus & 1300,12 & 780,07 & \\
\hline
\end{tabular}

Sumber: Data Primer (diolah), 200); $1 \mathrm{~kg}$ padi $=0,6 \mathrm{~kg}$ beras.

Rata-rata produksi padi sebanyak $2.265,63 \mathrm{Kg} / \mathrm{UT}$ atau $1.359,38 \mathrm{Kg}$ beras/UT dengan rendemen $60 \%$. Rendemen $60 \%$ diperoleh dari informasi petani dan data yang ada di Dinas Pertanian Kota Bengkulu. Dengan rata-rata luas garapan responden 0,75 hektar, maka diperoleh rata-rata produksi usahatani padi di Kelurahan Kandang Limun dan Kelurahan Dusun Besar sebesar $3.006,43 \mathrm{~kg} / \mathrm{ha}$. Hasil penelitian yang dilakukan di Kelurahan Kandang Limun dan Kelurahan Dusun Besar menunjukkan bahwa jumlah alokasi produksi padi untuk konsumsi sebesar 13,66\%, dimana produksi yang dialokasikan untuk konsumsi ini disiapkan untuk persediaan konsumsi sampai panen berikutnya (antara 3 sampai 4 bulan).

Jenis padi yang biasa ditanam oleh petani adalah IR 64 dan ciherang dengan pertimbangan jenis padi tersebut masa produksinya cepat, berasnya lunak dan banyak disukai konsumen. Selain itu harganya jualnya juga lebih mahal. Jumlah produksi yang dialokasikan oleh 
petani untuk bibit adalah 1,34\%. Ini dikarenakan $61,80 \%$ petani tidak mengalokasikan hasil produksinya untuk bibit pada musim tanam berikutnya, melainkan mengalokasikan keuangan keluarga dari hasil penjualan beras atau dari penerimaan luar keluarga untuk membeli benih.

Di Kelurahan Kandang Limun dan Kelurahan Dusun Besar pemanenan dilakukan dengan sistem upahan yang dibayar dengan uang berdasarkan uapah harian. Sedangkan untuk biaya treser di Kelurahan Kandang Limun 11:1, artinya dalam 11 karung disisihkan 1 karung untuk biaya mesin perontok, untuk biaya mesin perontok di Kelurahan Dusun Besar 10:1 (1 karung $=50 \mathrm{~kg})$. Perbedaan ini disebakan karena di Kelurahan Dusun besar petani padi lebih banyak dan hasil yang diperoleh juga lebih banyak serta jarak antara sawah dekat sehingga biaya mesin lebih murah. Pada Tabel 1 dapat dilihat jumlah produksi yang dialokasikan untuk upah treser rata-rata sebesar $9,39 \%$.

Upah penggilingan RMU menetapkan bagi hasil 10:1, artinya setiap giling gabah 10 cupak, dikeluarkan upah giling 1 cupak ( 1 cupak $=1,5 \mathrm{~kg}$ ). Jumlah alokasi produksi usahatani padi yang digunakan untuk upah giling rata-rata adalah $8,63 \%$. Biasanya masing-masing RMU menawarkan fasilitas bagi konsumennya berupa penyediaan gudang dan tempat penjemuran secara gratis. Selain menawarkan jasa penggilingan, RMU juga membeli beras hasil produksi petani.

Rata-rata alokasi produksi yang digunakan untuk sewa lahan pada penelitian sebesar $6,36 \%$. Sewa lahan dihitung berdasarkan kesepakatan antara pemiliki dan penyewa. Sistem sewa bagi hasil dengan perbandingan 3:1 artinya dalam tiga karung produksi padi dikeluarkan sewa lahan 1 karung $(1 \mathrm{karung}=50 \mathrm{~kg}$ ). Hasil penelitian menunjukkan bahwa terdapat 35,96\% petani penyewa dan $64,04 \%$ petani pemiliki.

Hasil penelitian menunjukkan bahwa $34,83 \%$ petani mengalokasikan hasil produksinya untuk zakat. Dimana zakat padi harus dikeluarkan sebanyak 10\% dari hasil produksi apabila 
sudah cukup nisab yaitu $1.250 \mathrm{~kg}$ baik untuk sawah irigasi maupun sawah tadah hujan. Besarnya zakat dan nisab wajib zakat antara sawah irigasi dan tadah hujan disebabkan karena petani yang memiliki sawah irigasi tidak ada membayar iuran irigasi. total produksi yang dialokasikan untuk zakat rata-rata sebesar $3,24 \%$ dari total produksi.

Setelah petani mengeluarkan hasil produksi untuk kebutuhan konsumsi, upah yang bersifat natura, sewa lahan, bibit dan zakat maka sisa dari hasil produksi tersebut dijual untuk memenuhi kebutuhan keluarganya. Rata-rata marketable surplus beras di Kota Bengkulu musim tanam Maret 2007 adalah 780,07 Kg/UT beras dengan jumlah marketable surplus beras sebesar 69.426,26 Kg. Dari hasil tersebut diperoleh persentase marketable surplus beras di Kota Bengkulu sebesar $57,38 \%$ sementara $42,62 \%$ digunakan untuk konsumsi, bibit, upah treser, upah giling dan zakat.

Marketed supply merupakan kuantitas atau jumlah padi/beras yang dipasarkan oleh petani setelah 3 bulan panen. Jumlah marketed supply merupakan jumlah dari marketable surplus, setelah petani mengeluarkan hasil produksi untuk kebutuhan konsumsi, upah yang bersifat natura, sewa lahan, bibit, dan zakat maka hasil produksi tersebut dijual untuk memenuhi kebutuhan hidup keluarga dan untuk modal usahatani musim tanam berikutnya. Jumlah marketed supply adakalanya tidak sama dengan jumlah marketable surplus (Tabel 2).

Tabel 2. Perbandingan Jumlah Marketable Surplus dan Marketed Supply Beras di Lokasi Penelitian

\begin{tabular}{ccc}
\hline $\begin{array}{c}\text { Jumlah marketable surplus } \\
\text { beras }(\mathbf{k g})\end{array}$ & $\begin{array}{c}\text { Jumlah marketed supply } \\
\text { beras }(\mathbf{k g})\end{array}$ & $\begin{array}{c}\text { Sisa marketable surplus } \\
\text { beras }(\mathbf{k g})\end{array}$ \\
\hline $69.426,26$ & $50.621,65$ & $18.804,61$ \\
\hline
\end{tabular}

Jumlah marketable surplus beras di daerah penelitian sebesar $69.426,26 \mathrm{~kg}$, sementara masih ada sebesar $18.804,61 \mathrm{~kg}$ atau $27,09 \%$ yang belum dijual oleh petani. sedangkan sisanya belum menjual semua beras yang dapat dipasarkan. Hal ini disebabkan karena sebagian petani masih menyimpan hasil panennya, karena mereka masih menunggu harga beras mahal dan 
menungggu ketika mereka membutuhkan uang baru dijual. Marketable surplus beras yang belum dijual akan dijual oleh petani sebelum waktu panen tiba, karena petani tidak akan menyimpan hasil panennya lebih lama dan mereka juga pasti membutuhkan uang tunai untuk membayar upah tenaga kerja, seperti untuk upah menyabit.

\section{Faktor Yang Mempengaruhi Marketed Supply Beras}

Marketed Supply beras diduga dengan menggunakan model persamaan linier berganda dengan metode OLS (Ordinary Least Square). Dalam hal ini marketed supply beras merupakan fungsi dari harga beras, penerimaan luar usahatani padi, indeks pertanaman, dan status penerimaan usahatani padi (Tabel 3).

Tabel 3. Hasil Estimasi Model Marketed Supply Beras di Lokasi Penelitian

\begin{tabular}{|c|c|c|c|c|}
\hline No & Variabel Bebas & $\begin{array}{c}\text { Koefisien } \\
\text { Regresi }\end{array}$ & $\begin{array}{l}\text { Standard } \\
\text { Error }\end{array}$ & $T_{\text {hitung }}$ \\
\hline 1. & Harga Beras (X1) & 0,56067 & 0,15127 & $3,70625^{\star * *}$ \\
\hline 2. & $\begin{array}{l}\text { Penerimaan Luar Usahatani Padi } \\
\text { (X2) }\end{array}$ & 0,05211 & 0,01471 & $3,54388^{* * *}$ \\
\hline 3. & Indeks Pertanaman (X3) & 70,33613 & 55,77916 & $-1,26098$ \\
\hline 4. & $\begin{array}{l}\text { Status Penerimaan Usahatani Padi } \\
\text { (X4) }\end{array}$ & 659,91231 & 72,00495 & $9,16482^{\star * *}$ \\
\hline & 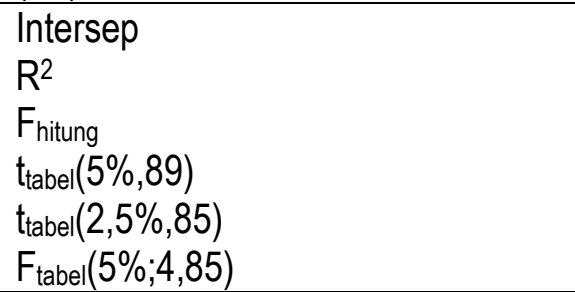 & $\begin{array}{l}-2416,98593 \\
0,60 \\
31,96005 \\
1,986978657 \\
2,27995079 \\
1,426981704\end{array}$ & & \\
\hline
\end{tabular}

Keterangan:

*** Signifikan pada $\mathrm{a} / 2=0,025$

Koefisien determinasi $\left(\mathrm{R}^{2}\right)$ dari model penelitian marketed supply beras di Kota Bengkulu adalah 0,60 . Nilai ini menunjukkan bahwa variabel jumlah marketed supply beras dijelaskan oleh variabel harga beras, penerimaan luar usahatani padi, indeks pertanaman dan status penerimaan usahatani padi sebesar $60 \%$. Sedangkan $40 \%$ lagi dijelaskan oleh variabel yang tidak dimasukkan dalam model ini, diduga seperti harga-harga barang lain kebutuhan petani selain beras, luas lahan dan sistem pembayaran pupuk urea. Pengaruh variabel bebas secara bersama-sama terhadap 
variabel terikat diuji dengan menggunakan uji F. Dari Tabel 3 dapat dilihat besarnya $F_{\text {hitung }}$ $(31,96005)$ lebih besar dari $F_{\text {tabel }}(1,426981704)$ pada $a=0,05$. Artinya variabel bebas secara bersama-sama berpengaruh nyata terhadap variabel terikat pada taraf keyakinan $95 \%$.

Hasil estimasi model marketed supply beras menunjukkan bahwa variabel indeks pertanaman tidak memberikan pengaruh yang signifikan pada taraf keyakinan $95 \%$. Sedangkan variabel harga beras, penerimaan luar usahatani padi dan status penerimaan usahatani padi berpengaruh nyata terhadap marketed supply.

Hasil pengujian statistik menunjukkan bahwa nilai thitung peubah total produksi lebih besar dari ttabel pada taraf kepercayaan 95\%, dapat disimpulkan bahwa harga beras memiliki tanda positif terhadap perubahan marketed supply beras sesuai dengan hipotesis awal. Hal ini sesuai dengan hukum penwaran yaitu semakin tinggi harga suatu barang, maka produk yang ditawarkan akan meningkat. Begitu juga dengan beras, semakin tinggi harga beras maka petani akan semakin banyak menjual beras. Petani berharap dengan tingginya harga beras maka mereka bisa memperoleh penerimaan yang lebih besar, sehingga mereka sengaja menyimpan hasil panennya dan baru menjual saat harga beras mahal.

Variabel penerimaan luar usahatani padi bertanda positif dan berpengaruh nyata terhadap marketable surplus beras. Semakin besar penerimaan yang diperoleh petani dari luar usahatani padi maka kesempatan petani untuk menjual beras lebih banyak, karena semakin kaya seorang petani maka semakin banyak jumlah padi yang dapat dijual oleh petani. Petani tidak perlu menyimpan beras lebih banyak untuk konsumsi karena mereka bisa membeli kembali apabila terjadi kekurangan dengan penerimaan luar usahatani yang mereka peroleh.

Indeks pertanaman tidak memberikan pengaruh yang nyata dan bertanda negatif terhadap merketed supply beras. Hal ini disebabkan karena indeks pertanaman di daerah penelitian masih rendah, selain karena banyak yang tidak menggunakan sawah irgasi juga disebabakan oleh 
musim kemarau. Jadi meskipun indek pertanaman tinggi, karena musim kemarau maka hasil panen yang diperoleh sedikit sehingga jumlah beras yang dipasarkan juga sedikit.

Status penerimaan utama keluarga mempunyai hubungan yang positif dan mempunyai pengaruh yang signifikan terhadap marketed supply beras karena apabila usahatani padi merupakan sumber penerimaan utama keluarga maka untuk menutupi kebutuhan keluarganya petani akan lebih banyak menjual hasil produksi padinya. Intinya petani banyak menjual hasil produksinya karena ingin menutupi kebutuhan keluarga yang lain seperti biaya sekolah sehingga mereka harus menjual produksi lebih banyak dibandingkan dengan petani yang memiliki penerimaan luar usahatani lebih besar.

Ketersediaan beras di Kota Bengkulu dapat dilihat dari jumlah produksi yang dihasilkan oleh petani atau marketable surplus beras pada musim tanam Maret 2007 (Tabel 4):

Tabel 4. Ketersediaan Beras di Kota Bengkulu

\begin{tabular}{lr}
\hline \multicolumn{1}{c}{ Uraian } & \multicolumn{1}{c}{ Jumlah } \\
\hline Jumlah penduduk yang mengkonsumsi beras pada tahun 2006 & 272.594 \\
sebanyak 273.016 orang (dikurangi 422 orang) & 126 \\
Konsumsi perkapita / tahun (kg) & 34.346 .844 \\
Jumlah kebutuhan beras (kg/th) & 11.443 .948 \\
Kebutuhan beras selama 4 bulan / 1 musim tanam (kg) & $201.641,2$ \\
Produksi padi di daerah penelitian (kg/GKG) & \\
Produksi beras di daerah penelitian (produksi x 60\%) (Kg) & $120.984,72$ \\
Marketable surplus beras di daerah penelitian (kg) (dari 89 petani & $69.426,26$ \\
responden) & $(0,61 \%)$ \\
Kontribusi beras dari upah giling yang dibayarkan 89 petani & $10.445,93$ \\
responden pada Rice Miling Unit (kg) & $79.872,19$ \\
Total kontribusi beras dari 89 petani responden di daerah penelitian & $8.784 .051,39$ \\
\hline
\end{tabular}

Kebutuhan beras untuk Kota Bengkulu 4 bulan yang akan datang sebanyak 11.443 .948 $\mathrm{kg}$. Beras yang berasal dari daerah penelitian sebanyak $79.872,19 \mathrm{~kg}$, dengan rincian: marketable surplus petani sebesar $69.426,26 \mathrm{~kg}$ dan upah giling yang dibayarkan petani kepada RMU sebanyak 10.445,93 kg. Sedangkan sisanya disediakan oleh Perum Bulog yang nantiya dibagi 
dalam Raskin, OPM, dan jatah beras karyawan Bulog. Sisanya juga dipasok dari berbagai daerah sentra produksi di Propinsi Bengkulu (seperti: Seginim, Manna, dan Padang Guci) dan luar Propinsi Bengkulu seperti dari Propinsi Lampung yang banyak dijual di toko-toko beras dan Propinsi Palembang. Berdasarkan informasi yang diperoleh dari toko beras Sembilan Pilar di pasar Panorama, beras yang mereka jual semuanya adalah beras Lampung yang sudah dikemas dalam kemasan dengan rata-rata pemesanan \pm 200 ton/bulan. Sedangkan informasi dari toko beras Hery di pasar Panorama, beras yang dijual berasal dari Lampung, Palembang, Seginim, Manna, dan Padang Guci dengan rata-rata pemesanan 24 ton/bulan.

Data mengenai jumlah stok beras untuk Kota Bengkulu dari bulan Juni sampai Oktober yang diperoleh dari Perum Bulog Divisi Regional Bengkulu adalah sebanyak 8.784.051,39 kg. Dimana jumlah stok ini digunakan untuk berbagai macam pengeluaran seperti raskin, bantuan sosial bencana alam, maupun operasi pasar murni untuk menstabilkan harga beras di pasar apabila harganya naik. Berdasarkan data di atas maka ketersediaan beras di Kota Bengkulu masih sangat sedikit dan tidak mencukupi untuk kebutuhan beras di Kota Bengkulu.

\section{KESIMPULAN}

Berdasarkan hasil penelitian usahatani padi di Kelurahan Kandang Limun Kecamatan Muara Bangkahulu dan Kelurahan Dusun Besar Kecamatan Gading Cempaka Kota Bengkulu pada musim tanam Maret 2007 dapat diambil kesimpulan bahwa marketable surplus beras di daerah penelitian adalah $57,38 \%$ atau sebesar $69.426,26 \mathrm{~kg}$. Sisanya sebesar $42,62 \%$ digunakan untuk kebutuhan konsumsi, bibit, zakat, sewa lahan upah treser dan upah giling. Selain itu hasil penelitian juga menyimpulkan bahwa Faktor-faktor yang mempengaruhi marketed supply beras adalah: harga beras, penerimaan luar usahatani padi dan status penerimaan usahatani padi.

Ketersediaan beras di Kota Bengkulu untuk 4 bulan yang akan datang atau sampai waktu

panen berikutnya tiba berasal dari petani responden sebesar $69.426,26 \mathrm{~kg}$, Perum Bulog 
sebanyak $8.784 .051,39 \mathrm{~kg}$ dan sisanya berasal petani-petani lain yang ada di Kota Bengkulu, serta beras yang berasal dari luar Kota Bengkulu.

\section{DAFTAR PUSTAKA}

Arifin B et al. 1997. Pemberdayaan Lahan Kering untuk Penyediaan Pangan Abad 21. PERHEPI.

Nazir M. 1983. Metode Penelitian. Penerbit: Ghalia Indonesia. Jakarta.

Sofyan H. 2006. Marketable Surplus dan Lembaga Pemasaran Beras di Desa Dusun Muara Aman Kec. Lebong Utara Kab. Lebong. Skripsi. Jurusan Sosial Ekonomi Pertanian Universitas Bengkulu. Bengkulu (tidak dipublikasikan). 